\title{
Bcl-2 prevents mitochondrial permeability transition and cytochrome $c$ release via maintenance of reduced pyridine nucleotides
}

\author{
AJ Kowaltowski ${ }^{1,2}, \mathrm{AE}$ Vercesi ${ }^{2}$ and G Fiskum ${ }^{\star, 1}$ \\ 1 Department of Anesthesiology, The University of Maryland Baltimore, \\ Baltimore, MD, USA \\ 2 Departamento de Patologia Clínica, Faculdade de Ciências Médicas, \\ Universidade Estadual de Campinas, Campinas, SP, Brazil \\ * Corresponding author: G Fiskum, The University of Maryland at Baltimore \\ Anesthesiology Research Lab, Medical School Teaching Facility 5-34, 685 \\ West Baltimore Street, Baltimore, Maryland, MD, 21201 USA. \\ Tel: +01(410)706-4711; Fax:+01(410)706-2550; \\ E-mail:gfisk001@umaryland.edu
}

Received 21.12.99; revised 28.3.00; accepted 11.5.00

Edited by JC Reed

\begin{abstract}
Digitonin-permeabilized PC12 and GT1-7 neural cells exhibited a cyclosporin A-sensitive decrease in mitochondrial membrane potential, increased volume, and release of the proapoptotic factor cytochrome $c$ in the presence of $\mathrm{Ca}^{2+}$ and the mitochondrial permeability transition (MPT) inducers t-butyl hydroperoxide ( $t-\mathrm{bOOH})$ or phenylarsine oxide ( $\mathrm{PhAsO})$. Although the concentration of $\mathrm{PhAsO}$ required to induce the MPT was similar for $\mathrm{Bcl}-2$ negative and $\mathrm{Bcl}-2$ overexpressing transfected cells (Bcl-2(+)), the level of $t-\mathrm{bOOH}$ necessary for triggering the MPT was much higher for $\mathrm{Bcl}-2(+)$ cells. A higher concentration of $t-b O O H$ was also necessary for promoting the oxidation of mitochondrial pyridine nucleotides in $\mathrm{Bcl}-2(+)$ cells. The sensitivity of $\mathrm{Bcl}-2(-)$ cell mitochondria to $t-b O O H$ but not $\mathrm{PhAsO}$ could be overcome by the use of conditions that protect the pyridine nucleotides against oxidation. We conclude that the increased ability of $\mathrm{Bcl}-2(+)$ cells to maintain mitochondrial pyridine nucleotides in a reduced redox state is a sufficient explanation for their resistance to MPT under conditions of oxidative stress induced by $\mathrm{Ca}^{2+}$ plus $\mathrm{t}-\mathrm{bOOH}$. Cell Death and Differentiation (2000) 7, 903-910.
\end{abstract}

Keywords: apoptosis; calcium; oxidative stress; pyridine nucleotides

Abbreviations: FCCP, carbonyl cyanide p-trifluoromethoxyphenylhydrazone; CsA, cyclosporin $\mathrm{A} ; \Delta \Psi$, mitochondrial membrane potential; MPT, mitochondrial permeability transition; $\mathrm{PhAsO}$, phenylarsine oxide; ROS, reactive oxygen species; $t-\mathrm{bOOH}, t$ butyl hydroperoxide

\section{Introduction}

Mitochondrial isolated from a wide variety of tissues are capable of undergoing a $\mathrm{Ca}^{2+}$-induced, nonselective inner mitochondrial membrane permeabilization, known as the mitochondrial permeability transition (MPT). ${ }^{1-3}$ MPT begins as a permeabilization of the inner mitochondrial membrane to protons, resulting in a drop in mitochondrial membrane potential $(\Delta \Psi)$, and progresses as a loss of electrophoretic $\mathrm{Ca}^{2+}$ uptake capacity with associated osmotic swelling of the organelle and eventually even loss of matrix proteins. During this process, the mitochondrial outer membrane may rupture and release cytochrome $c$ from the intermembrane space into the cytosol, an event that has been demonstrated to be a trigger of apoptotic cell death. ${ }^{4,5}$ MPT-mediated impairment of mitochondrial activities may also be a cause of necrotic cell death under situations such as ischemia/reperfusion. ${ }^{6,7}$ Cyclosporin A is an efficient MPT inhibitor in isolated mitochondrial suspensions, and its effects on mitochondria and cell survival have been used as markers for MPT in various cell death paradigms. ${ }^{6,8-10}$

$\mathrm{Bcl}-2$ is an anti-apoptotic protein located primarily in the outer mitochondrial membrane, mostly at the contact sites where the outer membrane is closely associated with the inner mitochondrial membrane. ${ }^{11}$ The anti-apoptotic activity of this protein has been related to its property to prevent the release of cytochrome $c$ from mitochondria. ${ }^{12,13} \mathrm{Bcl}-2$ has also been demonstrated to inhibit MPT, ${ }^{14-16}$ although the mechanism by which this protection occurs has not been clearly elucidated. Evidence indicates that Bcl-2 offers mitochondria an increased resistance against a decline in membrane potential, ${ }^{15}$ while also increasing the total mitochondrial $\mathrm{Ca}^{2+}$ uptake capacity, ${ }^{17}$ properties that likely relate to the prevention of MPT.

$\mathrm{Bcl}-2$ overexpression also results in a shift in the cellular redox state toward a more reduced level. ${ }^{18}$ Since the occurrence of MPT has been linked to an oxidized shift in the mitochondrial redox state and/or increase in mitochondrial generation of reactive oxygen species (ROS), ${ }^{3}$ the resistance of $\mathrm{Bcl}-2$ overexpressing cells to MPT may be related to this higher reductive capacity. Indeed, we have shown previously that MPT promoted by several inducers, including $t$-butyl hydroperoxide $(t$ $\mathrm{bOOH})^{19}$ and inorganic phosphate, ${ }^{20,21}$ depends on the generation of ROS. In this report, we investigate the mechanism by which $\mathrm{Bcl}-2$ inhibits MPT. Our findings suggest that the maintenance of relatively reduced $\mathrm{NAD}(\mathrm{P}) \mathrm{H}$ in $\mathrm{Bcl}-2$ overexpressing cells is sufficient to explain their increased resistance to MPT.

\section{Results}

In suspensions of isolated mitochondria, nonspecific mitochondrial permeabilization due to the permeability transition can be followed by measuring the decrease in absorbance of the suspension as a result of mitochondrial swelling. ${ }^{1}$ As an 
alternative, investigators often monitor the drop in $\Delta \Psi$ as a marker of MPT.,8,9 In this work, we have studied MPT as assessed by the decline in mitochondrial $\Delta \Psi$ measured by changes in safranine $O$ fluorescence within suspensions of digitonin-permeabilized cells. ${ }^{22}$ At the concentration of digitonin used in these experiments, membrane cholesterol and other $\beta$-hydroxysterols bind to digitonin in a manner where the plasma membrane becomes freely permeable to solutes and molecules without affecting the structure or permeability of mitochondrial membranes. Digitonin-permeabilized cells can therefore be utilized as a convenient substitute for isolated mitochondria and often provide information more representative of mitochondrial activities as they exist within cells than that provided by isolated mitochondria.

Figure 1 displays typical strip-chart recorder tracings of mitochondrial $\Delta \Psi$ sustained by malate/glutamate-supported (NADH-linked) respiration in digitonin-permeabilized PC12 cells. $\mathrm{Ca}^{2+}$ was added at a concentration of $8 \mu \mathrm{M}$ as a necessary cofactor for the induction of the MPT by prooxidants. In the absence of added prooxidants, both $\mathrm{Bcl}-2(-)$ and $\mathrm{Bcl}-2(+)$ cells were capable of generating and maintaining $\Delta \Psi$ for over 10 min (upper panels, lines a). Thus the presence of $8 \mu \mathrm{M} \mathrm{Ca}^{2+}$ alone was not sufficient to induce the MPT under these conditions. Note, however, that the $\Delta \Psi$ of the $\mathrm{Bcl}-2(+)$ cells is apparently larger than
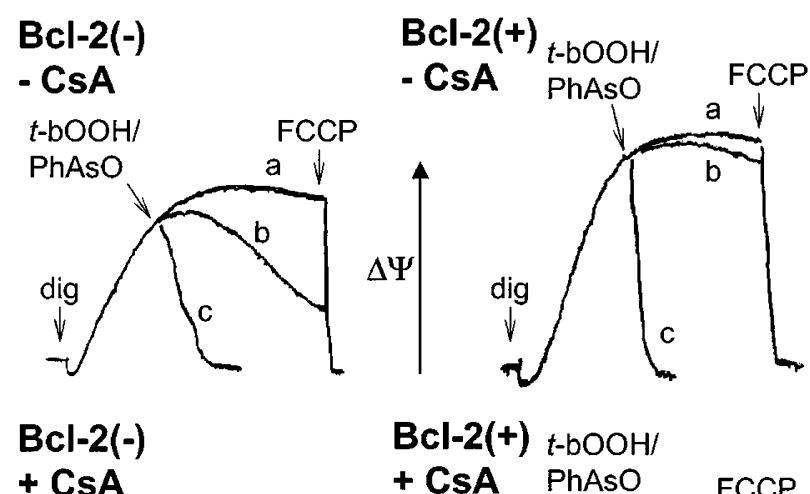

+ CsA

$\mathrm{Bcl}-2(+) t-\mathrm{bOOH} /$

+ CsA PhAsO
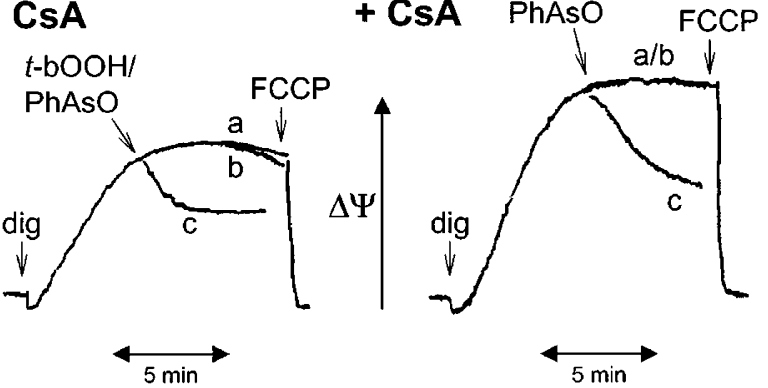

Figure 1 Inhibition by $\mathrm{Bcl}-2$ and cyclosporin $\mathrm{A}$ of pro-oxidant induced decline in mitochondrial membrane potential $(\Delta \Psi)$ of PC12 cells. Bcl-2(-) or $(+) \mathrm{PC} 12$ cells $\left(2 \times 10^{7} / \mathrm{ml}\right)$ were incubated in standard reaction medium containing malate plus glutamate as oxidizable substrates, $8 \mu \mathrm{M} \mathrm{Ca}^{2+}$, and $5 \mu \mathrm{M}$ safranine $\mathrm{O}$ for fluorescent measurement of mitochondrial $\Delta \Psi$. Digitonin (dig) was added at $0.01 \% \mathrm{w} / \mathrm{v}$ to permeabilize the plasma membrane of the cells in suspension. Subsequently, either the dimethylsulfoxide vehicle (line a) or $200 \mu \mathrm{M} \mathrm{t}$-bOOH (line b) or $15 \mu \mathrm{M} \mathrm{PhAsO} \mathrm{(line} \mathrm{c)} \mathrm{were} \mathrm{added.} \mathrm{The}$ fluorescent detection of changes in $\Delta \Psi$ was confirmed by the addition of $1 \mu \mathrm{M}$ FCCP. Experiments were performed in the absence (upper panels) or presence (lower panels) of $1 \mu \mathrm{M}$ cyclosporin $\mathrm{A}$ (CsA) the $\mathrm{Bcl}-2(-)$ cells. This difference was observed even in the absence of $\mathrm{Ca}^{2+}$, and when using suspensions of mitochondria isolated from these cells (not shown), confirming that the higher apparent $\Delta \Psi$ (lower safranine fluorescence) in the $\mathrm{Bcl}-2(+) \mathrm{PC} 12$ cells cannot be attributed only to a larger content of mitochondria or to a difference in response to the presence of low $\mathrm{Ca}^{2+}$ levels.

When the suspensions of digitonin-permeabilized cells were treated with the MPT inducer phenylarsine oxide (PhAsO, $15 \mu \mathrm{M})^{23}$ (upper panels, lines $\mathrm{c}$ ), a substantial decrease in $\Delta \Psi$ was observed in both $\mathrm{Bcl}-2(-)$ and $\mathrm{Bcl}-$ $2(+)$ cells. Addition of the alternative MPT inducer $t$-butyl hydroperoxide $(t-\mathrm{bOOH}, 200 \mu \mathrm{M})^{19}$ to the cell suspensions induced a $\mathrm{Ca}^{2+}$-dependent drop in $\Delta \Psi$ in the PC12 Bcl$2(-)$ cells, but not in the $\mathrm{Bcl}-2(+)$ cells (lines b). These observations suggest that $\mathrm{Bcl}-2$ selectively inhibits MPT, depending on the inducer used. When the MPT inhibitor cyclosporin A was present in the cellular suspensions, (lower panels), the drop in $\Delta \Psi$ induced by $\mathrm{PhAsO}$ (lines $\mathrm{c}$ ) or $t$-bOOH (lines b) was substantially inhibited or eliminated, confirming the relationship between the MPT and the drop in $\Delta \Psi$. In the presence of cyclosporin $A$ and in the absence of added prooxidants, the apparent levels of $\Delta \Psi$ for both $\mathrm{Bcl}-2(-)$ and (+) PC12 cells were very similar
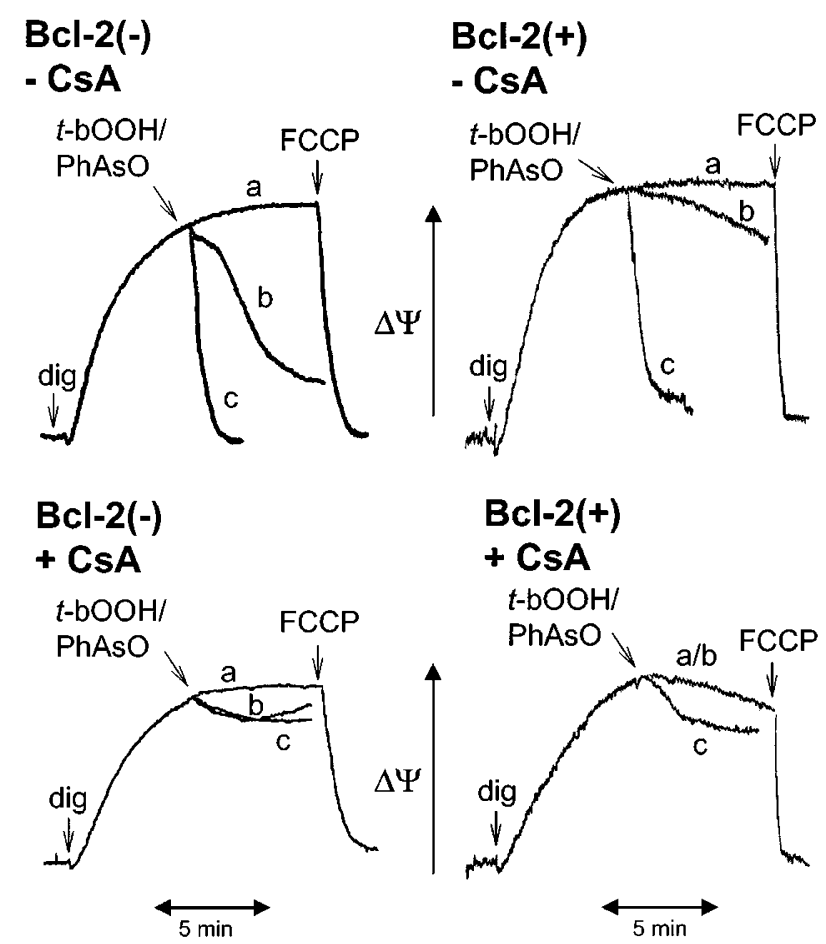

Figure 2 Inhibition by $\mathrm{Bcl}-2$ and cyclosporin $\mathrm{A}$ of pro-oxidant induced decline in mitochondrial membrane potential $(\Delta \Psi)$ of GT1-7 cells. Bcl-2(-) or (+) GT17 cells $\left(2 \times 10^{7} / \mathrm{ml}\right)$ were incubated in standard reaction medium containing malate plus glutamate as oxidizable substrates, $8 \mu \mathrm{M} \mathrm{Ca}^{2+}$, and $5 \mu \mathrm{M}$ safranine $O$ for fluorescent measurement of mitochondrial $\Delta \Psi$. Digitonin (dig) was added at $0.01 \% \mathrm{w} / \mathrm{v}$ to permeabilize the plasma membrane of the cells in suspension. Subsequently, either the dimethylsulfoxide vehicle (line a) or $200 \mu \mathrm{M} \mathrm{t}$-bOOH (line b) or $15 \mu \mathrm{M} \mathrm{PhAsO} \mathrm{(line} \mathrm{c)} \mathrm{were} \mathrm{added.} \mathrm{The}$ fluorescent detection of changes in $\Delta \Psi$ was confirmed by the addition of $1 \mu \mathrm{M}$ FCCP. Experiments were performed in the absence (upper panels) or presence (lower panels) of $1 \mu \mathrm{M}$ cyclosporin $\mathrm{A}$ (CsA) 
to those observed in the absence of cyclosporin $A$, providing further evidence that the limiting factor for the MPT was the prooxidant in these experiments.

In order to determine if the difference in sensitivity between $\mathrm{Bcl}-2(-)$ and $(+)$ cells to $t-\mathrm{bOOH}$ was specific for the PC12 cell line, we conducted the experiments shown in Figure 2 using the GT1-7 hypothalamic neural cell line. Although a higher $\mathrm{Ca}^{2+}$ load $(20 \mu \mathrm{M})$ was necessary to allow for the induction of MPT by prooxidants in GT1-7 cells, the differential effect of $\mathrm{Bcl}-2$ overexpression on MPT induction by prooxidants was comparable to that observed with the PC12 cells. Thus, while the drop in $\Delta \Psi$ induced by $t$-bOOH was inhibited by $\mathrm{Bcl}-2$ overexpression (lines $\mathrm{b}$ ), the loss of potential triggered by $\mathrm{PhAsO}$ was not influenced by the level of Bcl-2 (lines c). Cyclosporin A inhibited the drop in $\Delta \Psi$ in GT1-7 cells (lower panels), although a higher concentration $(5 \mu \mathrm{M})$ was required than that necessary for PC12 cells. Despite the qualitatively similar responses of PC12 and GT1-7 cells to prooxidants, the difference between the $\Delta \Psi$ for $\mathrm{Bcl}-2(-)$ and (+) GT1-7 cells observed in the absence of prooxidants or plus cyclosporin A was much less than the difference exhibited by $\mathrm{PC} 12$ cells (compare lines a for $\mathrm{Bcl}-2(-)$ vs $(+)$ ).

In isolated mitochondrial suspensions, MPT causes osmotic swelling due to influx of ions and small molecular weight compounds into the mitochondrial matrix where impermeant, large molecular weight proteins are highly concentrated. ${ }^{1}$ This alteration in the mitochondrial structure is thought to be the cause of mitochondrial release of cytochrome $c$ during MPT, since the swelling of the matrix space and unfolding of the inner membrane results in disruption of the relatively inflexible outer mitochondrial membrane. $^{24}$ In Figure 3 , we assessed changes in mitochondrial volume under conditions similar to Figure 1, using electron microscopy. As reported earlier for other cell types $^{22}$ the general appearance of $\mathrm{PC} 12$ cells was maintained following digitonin permeabilization of the plasma membrane. Also, no striking difference in cellular or mitochondrial morphology was apparent between the $\mathrm{Bcl}-2(-)$ and $\mathrm{Bcl}-2(+)$ cells (panels A). When the cells were treated with $\mathrm{Ca}^{2+}$ at a concentration $(8 \mu \mathrm{M})$ that did not induce a spontaneous decrease in mitochondrial $\Delta \Psi$ (see Figure 1), the mitochondria of both $\mathrm{Bcl}-2(-)$ and $\mathrm{Bcl}-2(+)$ cells appeared normal (panels B). However, the Bcl-2(-) cells displayed a substantial increase in mitochondrial volume and altered appearance when treated additionally with $t$-bOOH, while $\mathrm{Bcl}-2(+)$ mitochondria maintained characteristics similar to the controls (panels $\mathrm{C}$ ). Both Bcl$2(-)$ and $\mathrm{Bcl}-2(+)$ mitochondria were markedly swollen in the presence of $15 \mu \mathrm{M}$ PhAsO (panels D).

In a variety of experimental conditions, large amplitude mitochondrial swelling associated with MPT is followed by the release of cytochrome $c$ from the mitochondrial intermembrane space into the cytosol, an event that can trigger apoptotic cell death through caspase activation. ${ }^{25}$ Figure 4 depicts immunoblots used to detect cytochrome $c$ in the supernatants obtained following centrifugation of cell suspensions incubated under conditions similar to those used in the experiments described by Figures 1 and 2. We observed that all cell suspensions treated with $\mathrm{PhAsO}$ released cytochrome $c$ into the media, but only $\mathrm{Bcl}-2(-)$ cells released cytochrome $c$ upon the addition of $200 \mu \mathrm{M} \mathrm{t}$ $\mathrm{bOOH}$. Release of cytochrome $c$ under these conditions often approached the extent obtained in the presence of alamethicin, an artificial, non-specific pore former that induces massive mitochondrial swelling. Consistent with the effects on mitochondrial membrane potential (Figures 1 and 2), cyclosporin $A$ eliminated cytochrome $c$ release elicited by $\mathrm{Ca}^{2+}$ and $t-\mathrm{bOOH}$ and partially blocked the release induced by $\mathrm{Ca}^{2+}$ and $\mathrm{PhAsO}$.

Tert-butyl hydroperoxide is generally thought to induce the MPT indirectly, through its metabolism by glutathione

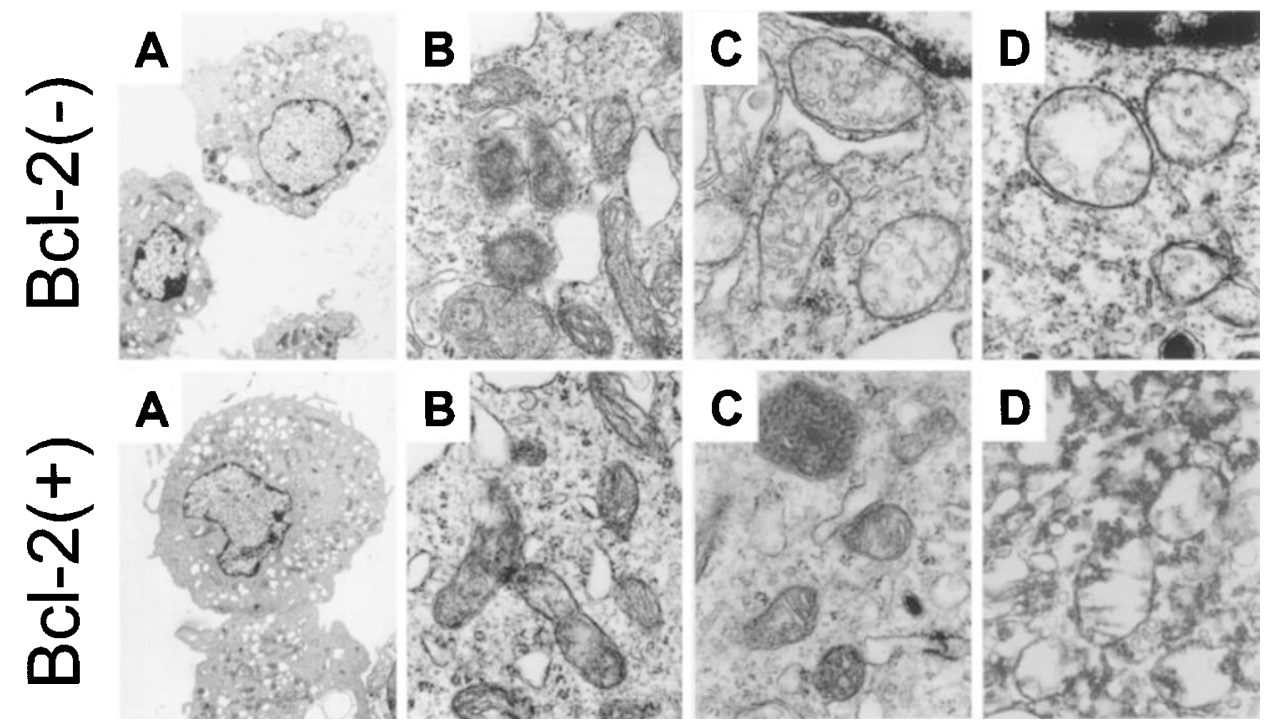

Figure 3 Electron microscopy of digitonin-permeabilized $\mathrm{Bcl}-2(-)$ and (+) PC12 cells in the absence and presence of pro-oxidants. PC12 cells were digitoninpermeabilized and incubated under the conditions described for Figure 1 for 20 min in the absence $(\mathbf{A}$ and $\mathbf{B})$, or presence of either $200 \mu \mathrm{M} t-\mathrm{bOOH}(\mathbf{C})$ or $15 \mu \mathrm{M}$ PhAsO (D). Magnification: $3500 \times($ panels A) and $30,000 \times($ panels B, C and D) 


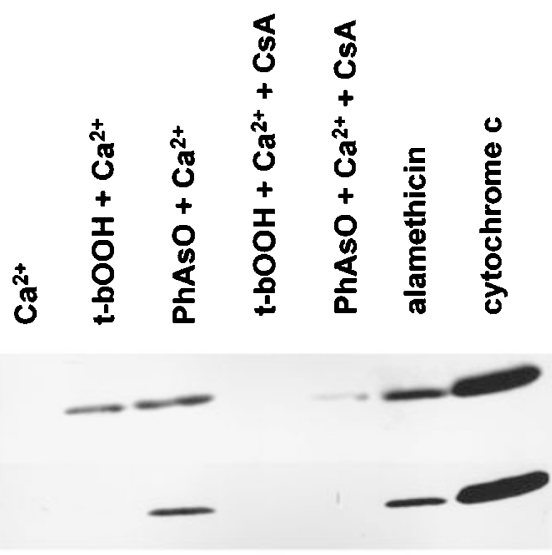

GT1-7 Bcl-2(-)

$\mathrm{Bcl}-\mathbf{2}(+)$

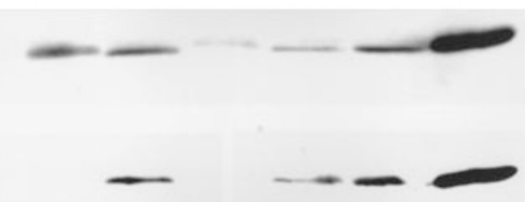

Figure 4 Inhibition by Bcl-2 and cyclosporin A of pro-oxidant induced release of cytochrome $c$ from permeabilized PC12 and GT1-7 cells. Supernatants obtained following centrifugation of digitonin-permeabilized cell suspensions $\left(1.6 \times 10^{8} / \mathrm{ml}\right.$ for PC12 cells and $8 \times 10^{7} / \mathrm{ml}$ for GT1-7 cells) incubated under the conditions described for Figures 1 and 2 were used for immunoblot detection of cytochrome $c$ (see Materials and Methods)

peroxidase and reductase leading to net oxidation of glutathione and pyridine nucleotides. ${ }^{19,26}$ This shift in redox state promotes the MPT by allowing for oxidation of protein sulfhydryls that regulate permeability transition pore opening. Previous studies indicate that Bcl-2 overexpression results in a reduced shift in cellular redox state. ${ }^{18}$ Other experiments indicate that mitochondria within $\mathrm{Bcl}-$ $2(+)$ cells are relatively resistant to pyridine nucleotide oxidation following mitochondrial uptake of extremely large amounts of $\mathrm{Ca}^{2+} \cdot 27$ We performed experiments such as those described in Figure 5 to determine if the resistance to the $t$-bOOH -induced drop in $\Delta \Psi$ afforded by Bcl-2 can be attributed to maintenance of a relatively reduced mitochondrial redox state. As shown by the representative measurements of $\mathrm{NAD}(\mathrm{P}) \mathrm{H}$ fluorescence, addition of 200 or $800 \mu \mathrm{M} \mathrm{t}$-bOOH to digitonin-permeabilized $\mathrm{Bcl}-2(-)$ PC12 cells resulted in rapid and extensive pyridine nucleotide oxidation that approached the degree of oxidation that can be elicited by maximizing respirationdependent $\mathrm{NAD}(\mathrm{P}) \mathrm{H}$ oxidation by the addition of a respiratory uncoupler. Exposure of $\mathrm{Bcl}-2(+)$ cells to $200 \mu \mathrm{M} t$-bOOH resulted in only partial pyridine nucleotide oxidation whereas the presence of $800 \mu \mathrm{M} \mathrm{t}-\mathrm{bOOH}$ elicited almost complete oxidation. A quantitative comparison of pyridine nucleotide oxidation by $t-\mathrm{bOOH}$ for $\mathrm{Bcl}-2(-)$ versus $(+)$ cells is also shown in Figure 5 . At $200 \mu \mathrm{M} t$ $\mathrm{bOOH}$, the extent of oxidation, expressed as a percentage of that obtained with uncoupler, was significantly less in $\mathrm{Bcl}-2(+)$ compared to $\mathrm{Bcl}-2(-)$ cells $(P<0.05, n=6)$. This oxidation of pyridine nucleotides could not be attributed to
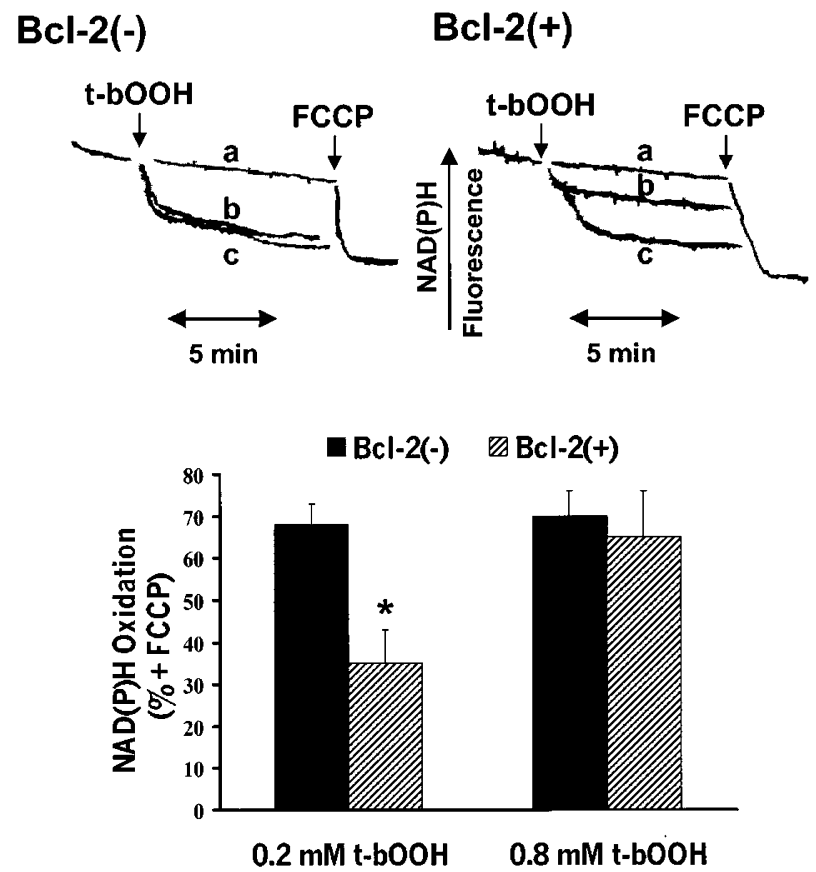

Figure 5 Effect of $\mathrm{Bcl}-2$ on the dose dependent oxidation of pyridine nucleotides by $t$-butyl hydroperoxide in permeabilized PC12 cells. PC12 cells $\left(2 \times 10^{7} / \mathrm{ml}\right)$ were incubated in standard reaction medium containing malate, glutamate, $\mathrm{Ca}^{2+}$, and digitonin. The top panels are representative examples of the autofluorescence emitted by reduced pyridine nucleotides $(\mathrm{NAD}(\mathrm{P}) \mathrm{H})$ at $352 \mathrm{~nm}$ excitation and $464 \mathrm{~nm}$ emission wavelengths in the absence (line a) or presence of either $200 \mu \mathrm{M} \mathrm{t}$-bOOH (line b) or $800 \mu \mathrm{M} t$-bOOH (line c). One $\mu \mathrm{M}$ FCCP was added to induce complete pyridine nucleotide oxidation. The bottom panel describes the means \pm S.E. $(n=6)$ for the pyridine nucleotide oxidation expression as a percentage of that observed upon addition of FCCP

the drop in membrane potential or additional oxidative stress following MPT since it was not inhibited by cyclosporin $\mathrm{A}$ or the absence of added $\mathrm{Ca}^{2+}$ (results not shown).

The experiments described in Figure 6 measuring changes in $\Delta \Psi$ with different concentrations of either $t$ $\mathrm{bOOH}$ or $\mathrm{PhAsO}$ were performed to verify if the increased resistance to pyridine nucleotide oxidation of the $\mathrm{Bcl}-2(+)$ cells observed in Figure 5 was indeed the cause of the increased resistance of these cells to MPT induced by $t$ $\mathrm{bOOH}$. In the upper panels, increasing concentrations of $t$ $\mathrm{bOOH}$ were added to both $\mathrm{Bcl}-2(-)$ and $\mathrm{Bcl}-2(+) \mathrm{PC} 12$ cells. Addition of $t$-bOOH to $\mathrm{Bcl}-2(-)$ cells at concentrations of $200 \mu \mathrm{M}$ (line b), $400 \mu \mathrm{M}$ (line c) or $800 \mu \mathrm{M}$ (line d) $t$-bOOH promoted essentially identical rates and extents of decline in $\Delta \Psi$, a result consistent with the observation in Figure 5 that $200 \mu \mathrm{M} t$-bOOH resulted in a nearly complete oxidization of pyridine nucleotides in $\mathrm{Bcl}-2(-)$ cells. However, in $\mathrm{Bcl}-2(+)$ cells, a $t$-bOOH dose-dependent loss of $\Delta \Psi$ was apparent with maximal loss apparent at only $800 \mu \mathrm{M} t$-bOOH (compare lines $\mathrm{b}-\mathrm{d}$ ). For both $\mathrm{Bcl}-2(-)$ and $(+)$ cells the drop in $\Delta \Psi$ was fully inhibited by cyclosporin $\mathrm{A}$ at all $t$-bOOH concentrations (lines a), confirming that changes in $\Delta \Psi$ reflect MPT activity. These comparisons therefore indicate that the MPT can be observed with $\mathrm{Bcl}-2$ overexpressing cells if sufficient levels 
of $t-\mathrm{bOOH}$ are added to promote extensive pyridine nucleotide oxidation. In contrast to the different dose-
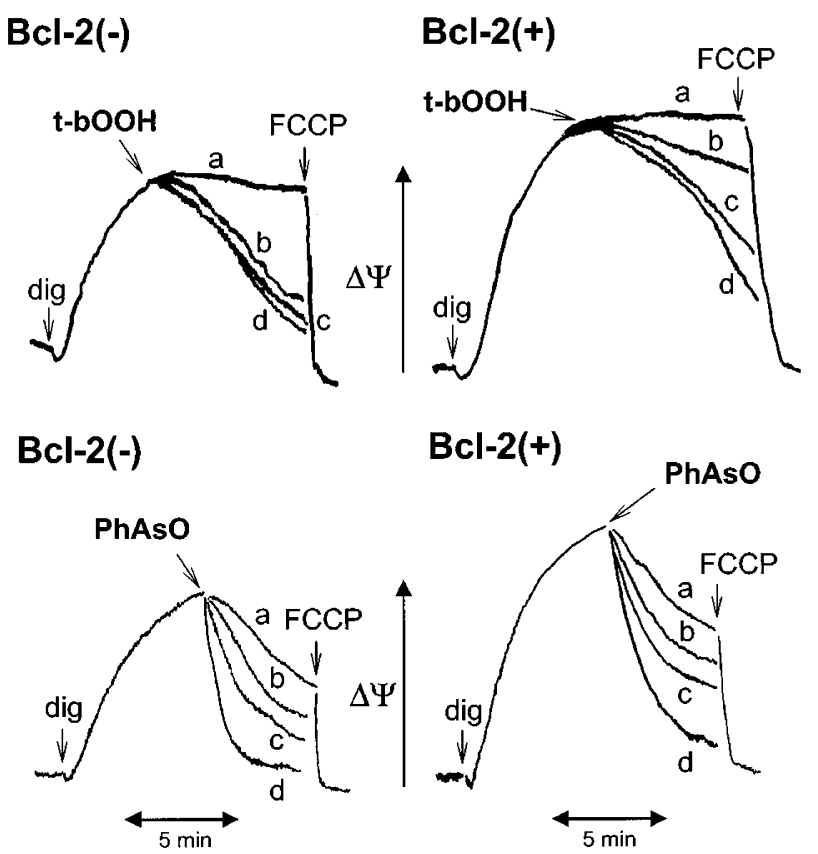

Figure 6 Effect of $\mathrm{Bcl}-2$ on the dose dependent decline in $\mathrm{PC} 12$ mitochondrial membrane potential $(\Delta \Psi)$ induced by $t$-butyl hydroperoxide compared to phenylarsine oxide. Bcl-2(-) or $(+) \mathrm{PC} 12$ cells $\left(2 \times 10^{7} / \mathrm{ml}\right)$ were incubated in standard reaction medium containing malate plus glutamate as oxidizable substrates, $8 \mu \mathrm{M} \mathrm{Ca}^{2+}$, and $5 \mu \mathrm{M}$ safranine $\mathrm{O}$ for fluorescent measurement of mitochondrial $\Delta \Psi$. Digitionin (dig) was added at $0.01 \% \mathrm{w} / \mathrm{v}$ to permeabilize the plasma membrane of the cells in suspension. In the upper panels, $t$-bOOH was added at a concentration of either $200 \mu \mathrm{M}$ (line b), $400 \mu \mathrm{M}$ (line $\mathrm{c}$ ), or $800 \mu \mathrm{M}$ (lines a and d). In line a, cyclosporin A was present at $1 \mu \mathrm{M}$. In the lower panels, PhAsO was added at a concentration of $2 \mu \mathrm{M}$ (line a), $5 \mu \mathrm{M}$ (line $\mathrm{b}$ ), $10 \mu \mathrm{M}$ (line $\mathrm{c}$ ), or $15 \mu \mathrm{M}$ (line d). The fluorescent detection of changes in $\Delta \Psi$ was confirmed by the addition of $1 \mu \mathrm{M}$ FCCP
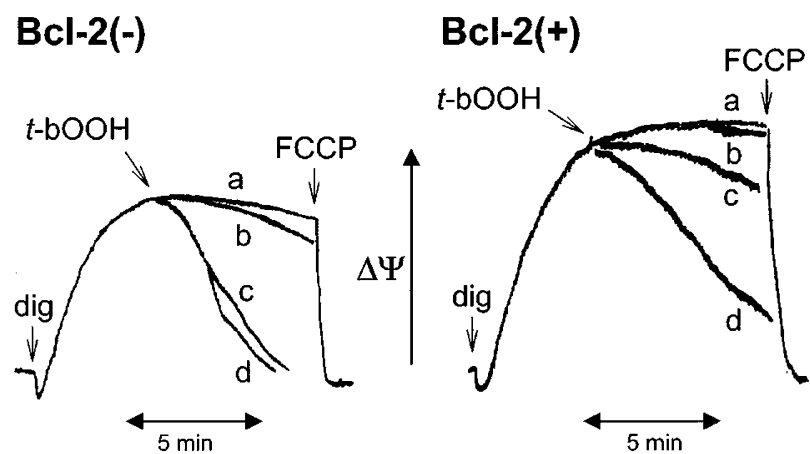

Figure 7 Effect of pyridine nucleotide redox state on mitochondrial permeability transition in $\mathrm{PC} 12$ cells respiring on succinate. Bcl-2(-) or $(+)$ PC12 cells $\left(2 \times 10^{7} / \mathrm{ml}\right)$ were incubated in standard reaction medium containing $5 \mathrm{mM}$ succinate as respiratory substrate, $8 \mu \mathrm{M} \mathrm{Ca}^{2+}$, and $5 \mu \mathrm{M}$ safranine $O$ for fluorescent measurement of mitochondrial $\Delta \Psi$. Digitonin (dig) was added at $0.01 \% \mathrm{w} / \mathrm{v}$ to permeabilize the plasma membrane of the cells in suspension. Rotenone $(1 \mu \mathrm{M})$ was present to block NAD(P)H oxidation by the respiratory chain. $200 \mu \mathrm{M} \mathrm{t}$-bOOH (lines a and c) or $800 \mu \mathrm{M} t$-bOOH (lines b and d) were added where indicated. FCCP was added at a concentration of $1 \mu \mathrm{M}$. In lines $\mathrm{a}$ and b, $5 \mathrm{mM}$ malate and $5 \mathrm{mM}$ glutamate were present as exogenous reductants of $\operatorname{NAD}(P)^{+}$whereas in lines $c$ and $d$, they were absent response relationships for $t-\mathrm{bOOH}$ induced MPT with $\mathrm{Bcl}$ $2(-)$ and $\mathrm{Bcl}-2(+)$ cells, similar dose-response relationships were observed for 2-15 $\mu \mathrm{M}$ PhAsO (Figure 6, lower traces). This result indicates that when MPT is triggered by a direct oxidant of protein sulfhydryl groups, $\mathrm{Bcl}-2$ is ineffective at inhibiting this phenomenon.

Experimental conditions were then modified in an attempt to make $\mathrm{Bcl}-2(-)$ and $(+)$ cells equally resistant to the MPT induced by $t-\mathrm{bOOH}$. In Figure 7 , we exposed permeabilized PC12 cells to the $\mathrm{NADH}$-linked substrates malate and glutamate in the presence of rotenone, which blocks the normal flow of electrons from pyridine nucleotides through the electron transfer chain. As rotenone inhibits Complex I (NADH-Coenzyme $\mathrm{Q}$ oxidoreductase) of the electron transport chain, mitochondrial $\Delta \Psi$ was established by the presence of succinate, a Complex II respiratory substrate insensitive to rotenone inhibition. Under these conditions, both $\mathrm{Bcl}-2(-)$ and $\mathrm{Bcl}-2(+) \mathrm{PC} 12$ cells presented a strong resistance to the drop in $\Delta \Psi$ normally induced by $t$-bOOH (lines $a$ and $b, 200$ and $800 \mu \mathrm{M}$, respectively). However, these conditions did not impair the ability of $\mathrm{PhAsO}$ to trigger a cyclosporin $\mathrm{A}$ sensitive drop in $\Delta \Psi$ (not shown). When malate and glutamate were omitted from the medium (lines $c$ and d), 200 and $800 \mu \mathrm{M} t$-bOOH evoked drops in $\Delta \Psi$ similar to what was observed with mitochondria respiring on these NAD-linked substrates (Figure 6). Again, Bcl-2(+) cells displayed a robust, $t$-bOOH-induced decline in $\Delta \Psi$ in the presence of 800 but not $200 \mu \mathrm{M} t-\mathrm{bOOH}$. Thus, the sensitivity of both $\mathrm{Bcl}-2(-)$ and $(+)$ cells to $t$-bOOH is dependent upon conditions that affect both the oxidation and reduction of pyridine nucleotides.

\section{Discussion}

$\mathrm{Bcl}-2$ has been widely demonstrated to inhibit apoptotic cell death induced by a variety of different stimuli, ${ }^{25,28}$ and probably acts by more than one mechanism. As an example, Bcl-2 can prevent the activation of caspases, ${ }^{25,29}$ thus preventing cell death induced by cytochrome $c$ microinjection. ${ }^{30} \mathrm{Bcl}-2$ has also been demonstrated to block cytochrome $c$ release from mitochondria, ${ }^{12,13}$ a pro-apoptotic occurrence upstream from caspase activation.

Cytochrome $c$ release can be induced by several triggers including intracellular redistribution of pro-apoptotic proteins, e.g., Bax, and by the accumulation of $\mathrm{Ca}^{2+}$ by mitochondria. ${ }^{24,29,31,32}$ Several lines of evidence indicate that in some apoptosis paradigms, one or more of these triggers activate the MPT, resulting in mitochondrial swelling, disruption of the outer membrane and release of cytochrome $c$ into the cytosol. ${ }^{2,16,24}$ Several studies have shown that $\mathrm{Bcl}-2$ prevents the onset of MPT, thus preventing the drop in $\Delta \Psi$, mitochondrial swelling and cytochrome $c$ release. ${ }^{14,15}$

In this report, we studied the mechanism by which Bcl-2 inhibits MPT. We found that MPT and cytochrome $c$ release can be promoted in both $\mathrm{Bcl}-2(-)$ and $\mathrm{Bcl}-2(+)$ cells when these cells were treated with PhAsO (Figures 1, 2, 3 and 4), with similar dose response relationships (Figure 6). However, $200 \mu \mathrm{M} \mathrm{t-bOOH}$ induced a substantial drop in mitochondrial membrane potential in $\mathrm{Bcl}-2(-)$ cells 
(Figures 1, 2, 3 and 4), whereas the MPT was only observed with $\mathrm{Bcl}-2(+)$ cells at extremely high concentrations of $t$-bOOH $(800 \mu \mathrm{M}$, Figures 6 and 7).

$\mathrm{PhAsO}$ and $t-\mathrm{bOOH}$ act by different mechanisms to induce MPT. $t$-bOOH oxidizes mitochondrial glutathione and pyridine nucleotides. Consequently, there is a depletion of substrates for mitochondrial glutathione peroxidase and reductase. Reduction in the activities of these enzymes results in an accumulation of $\mathrm{Ca}^{2+}$-stimulated mitochondrially-generated reactive oxygen species (ROS). ${ }^{19}$ The accumulated ROS then promote the oxidation of mitochondrial membrane protein thiols, resulting in the MPT.,19 $\mathrm{PhAsO}$ is a dithiol reagent that reacts directly with membrane protein thiols, promoting MPT independently of ROS or pyridine nucleotide oxidation.,33 Thus, our results indicate that Bcl-2 inhibits MPT at a step upstream of membrane protein thiol oxidation. Indeed, 4,4'-diisothiocyanatostilbene-2,2'-disulfonic acid and arsine oxide, two other MPT inducers which act as dithiol reagents, were also capable of inducing $\Delta \Psi$ decrease in both $\mathrm{Bcl}-2(-)$ and $\mathrm{Bcl}-$ $2(+)$ cells (results not shown).

Previously, Zamzami et $a l^{34}$ demonstrated that the dithiol reagent diamide can induce a drop in mitochondrial membrane potential and overcome the apoptosis-inhibitory effects of Bcl-2. Here, we used the drop in $\Delta \Psi$ induced by either a dithiol reagent or a hydroperoxide as a marker of the MPT and investigated the mechanism through which $\mathrm{Bcl}-2$ inhibits this loss of membrane potential and the associated loss of cytochrome $c$. The protection that $\mathrm{Bcl}-2$ overexpression confers against the oxidation of mitochondrial pyridine nucleotides provides a mechanistic explanation for the relative resistance of $\mathrm{Bcl}-2(+)$ cells to MPT induced by $t$-bOOH and the lack of resistance to $\mathrm{PhAsO}$. However, under some circumstances the MPT can induce the oxidation of pyridine nucleotides due to uncoupling or increased ROS production. ${ }^{35,36}$ We observed similar patterns of $t-\mathrm{bOOH}$-induced $\mathrm{NAD}(\mathrm{P}) \mathrm{H}$ oxidation in the absence or presence of the MPT inhibitor cyclosporin A. This result indicates that the effects of $t-\mathrm{bOOH}$ and $\mathrm{Bcl}-2$ on $\mathrm{NAD}(\mathrm{P}) \mathrm{H}$ oxidation preceed their effects on the MPT and associated cytochrome $c$ release.

Our hypothesis that a primary mechanism by which $\mathrm{Bcl}-2$ inhibits MPT is via maintenance of relatively reduced pyridine nucleotides was originally based on the finding of Ellerby et $a l^{18}$ that $\mathrm{Bcl}-2$ shifts the redox potential of several cell types to a reduced state. Our results are also consistent with those of Espositi et $\mathrm{al}^{37}$ who determined that $\mathrm{Bcl}-2$ overexpressing mitochondria exhibit an increased amount of $\mathrm{NAD}(\mathrm{P}) \mathrm{H}$, and are resistant to increases in cellular ROS generation induced by tumor necrosis factor. This hypothesis is further supported by the observation that $\mathrm{PhAsO}$, which acts by directly reacting with mitochondrial membrane protein thiols, ${ }^{24,33}$ can overcome the inhibition of MPT by Bcl-2 (Figures 1, 2 and 6). Also, treating $\mathrm{Bcl}-2(+)$ cells with very large concentrations of $t-\mathrm{bOOH}(800 \mu \mathrm{M})$ can promote an extensive pyridine nucleotide oxidation (Figure 5) and decrease in membrane potential (Figure 6). Finally, Bcl-2(-) cells exhibited the same resistance to $t-\mathrm{bOOH}$-mediated MPT as Bcl-2(+) cells when the pyridine nucleotide state was maintained reduced by the presence of malate and glutamate in the presence of rotenone (Figure 7). These results demonstrate the multifactorial control of MPT and how the influence of $\mathrm{Bcl}-2$ is affected by different experimental conditions that influence $\mathrm{NAD}(\mathrm{P}) \mathrm{H}$ redox state.

Our observations and those of others indicate that the $\Delta \Psi$ of $\mathrm{Bcl}-2$ overexpressing cells is higher than that of $\mathrm{Bcl}-$ $2(-)$ cells. As a decreased $\Delta \Psi$ promotes the MPT, it is possible that the elevated $\Delta \Psi$ of $\mathrm{Bcl}-2(+)$ cells is the primary determinant of MPT resistance, rather than the maintenance of reduced pyridine nucleotides. However, both PC12 and GT1-7 Bcl-2 overexpressors exhibit similar resistance to MPT induced by $t-\mathrm{bOOH}$ whereas the difference between the $\Delta \Psi$ of $\mathrm{Bcl}-2(-)$ and (+) GT1-7 cells is small compared to that for PC12 cells (Figures 1 and 2). Moreover, $\mathrm{Bcl}-2(-)$ and (+) $\mathrm{PC} 12$ cells exhibit comparable resistance to MPT in the presence of malate, glutamate, and rotenone while still exhibiting substantial differences in $\Delta \Psi$ (Figure 7). While it appears that the $\Delta \Psi$ is not the primary determinant of sensitivity to MPT in our system, it is quite possible that the unknown molecular mechanism responsible for the maintenance of relatively reduced pyridine nucleotides by $\mathrm{Bcl}-2$ is in some way responsible for the relatively elevated $\Delta \Psi$.

In our experiments, cytochrome $c$ release was elicited in a manner directly related to MPT and mitochondrial swelling (Figure 4). In cytochrome $c$-induced cell death, cytochrome $c$ release may occur by both MPT-dependent and independent mechanisms..$^{5,8,12,13,25}$ However, studies have shown that MPT and cytochrome $c$ release are early events in several models of apoptosis. ${ }^{5,8,12,13}$ Thus, our observations concerning the mechanisms of inhibition of MPT by $\mathrm{Bcl}-2$ provide a plausible explanation for the prevention of cytochrome $c$ release promoted by $\mathrm{Bcl}-2$ in many situations, and particularly under conditions that favor oxidative stress. This postulate is supported by the observation that $\mathrm{Bcl}-2$ prevention of apoptosis can be overcome by glutathione depletion of these cells ${ }^{38}$ and that $\mathrm{Bcl}-2$ protection against mitochondrial injury and cell death can be mimicked by $\mathrm{N}$-acetylcysteine, an antioxidant and precursor of glutathione. ${ }^{39-42}$

\section{Materials and Methods}

\section{Cell cultures}

PC12 and immortalized hypothalamic GT1-7 neuronal cell lines transfected with the $b c \mathrm{l}-2$ gene $(\mathrm{Bcl}-2(+))$ or with a control retroviral construct $(\mathrm{Bcl}-2(-))$ were maintained as described previously. ${ }^{17,43}$ Prior to the experiments, the cells were trypsinized and suspended in growth media supplemented with $5 \mathrm{mM}$ EGTA. Stock suspensions of cells were kept at room temperature for up to $5 \mathrm{~h}$. Cell viability, as assessed by a cell count in Trypan Blue, was $>90 \%$ during this period.

\section{Standard incubation conditions}

Just prior to digitonin permeabilization, the suspended cells were centrifuged and resuspended in $130 \mathrm{mM} \mathrm{KCl}, 5 \mathrm{mM} \mathrm{HEPES} \mathrm{(pH} \mathrm{7.0),}$ $5 \mathrm{mM}$ malate and $5 \mathrm{mM}$ glutamate at $30^{\circ} \mathrm{C}$. Other additions are described in the figure legends. The results described in each figure are representative of at least three independent experiments. 


\section{Determination of mitochondrial membrane potential $(\Delta \Psi)$}

Mitochondrial $\Delta \Psi$ was monitored by measuring the fluorescence changes of safranine $\mathrm{O}(5 \mu \mathrm{M})$ recorded on a Perkin-Elmer LS-3 fluorescence spectrophotometer equipped with continuous stirring, operating at excitation and emission wavelengths of 485 and $586 \mathrm{~nm}$, respectively. ${ }^{44}$ The fluorescence of safranine in cell or mitochondrial suspensions decreases as $\Delta \Psi$ increases, due to quenching as it accumulates within the mitochondria. The fluorescent recordings are presented in the figures so that an increase in the signal corresponds to an increase in $\Delta \Psi$.

\section{Electron microscopy}

Samples were fixed overnight in a $4 \%$ formaldehyde plus $1 \%$ glutaraldehyde solution, and postfixed in 1\% osmium tetroxide. Dehydration was performed in a series of ethanol and propylene oxide extractions, prior to sample embedding in Polibed ${ }^{\mathbb{R}} 812$. Sections were cut at 0.1 micron and stained with uranyl acetate plus lead citrate. Electron micrographs were obtained using a JOEL 1200 EX electron microscope.

\section{Measurements of cytochrome $c$ release}

Aliquots of the digitonin-permeabilized cell suspensions were centrifuged at $10000 \times g$ for $2 \mathrm{~min}$. The supernatants were collected and used for cytochrome $c$ immunoblots, performed with $7 \mathrm{H} 8$ mouse anti-cytochrome $c$ antibodies (PharMingen), as described previously. ${ }^{45}$

\section{Determination of $\mathrm{NAD}(\mathrm{P})$ redox state}

The redox state of pyridine nucleotides in digitonin-permeabilized cells was followed fluorometrically at $352 \mathrm{~nm}$ excitation and $464 \mathrm{~nm}$ emission wavelengths. Extent of pyridine nucleotide oxidation was calculated as a percentage of the oxidation induced by FCCP. Statistical difference between oxidation for $\mathrm{Bcl}-2(-)$ and $(+)$ cells was tested using Student's $t$-test.

\section{Materials}

$t$ - $\mathrm{bOOH}, \mathrm{PhAsO}$, safranine $\mathrm{O}$, rotenone, succinate, malate, glutamate, digitonin, FCCP and alamethicin were purchased from Sigma Chemical Co., Cyclosporin A was purchased from Alexis Corporation.

\section{Acknowledgements}

We thank SJ Russell for the excellent technical assistance. Transfected cells were kindly provided by Dr. Dale Bredesen, Buck Research Institute, CA, USA. Supported by FAPESP, NIH grant NS34152 and the Bayer Corporation.

\section{References}

1. Zoratti M and Szabò I (1995) The mitochondrial permeability transition. Biochim. Biophys. Acta 1241: 139-176

2. Bernardi $P$ (1996) The permeability transition pore. Control points of a cyclosporin A-sensitive mitochondrial channel involved in cell death. Biochim. Biophys. Acta 1275: 5-9
3. Vercesi AE, Kowaltowski AJ, Grijalba MT, Meinicke AR and Castilho RF (1997) The role of reactive oxygen species in mitochondrial permeability transition. Biosci. Rep. 17: 43-52

4. Cai J, Yang J and Jones DP (1998) Mitochondrial control of apoptosis: the role of cytochrome c. Biochim. Biophys. Acta 1366: 139-149

5. Kroemer G, Dallaporta B and Resche-Rigon M (1998) The mitochondrial death/ life regulator in apoptosis and necrosis. Annu. Rev. Physiol. 60: 619-642

6. Halestrap AP, Connern CP, Griffiths EJ and Kerr PM (1997) Cyclosporin A binding to mitochondrial cyclophilin inhibits the permeability transition pore and protects hearts from ischaemia/reperfusion injury. Mol. Cell. Biochem. 174: $167-172$

7. Lemasters JJ, Nieminen AL, Qian T, Trost LC and Herman B (1997) The mitochondrial permeability transition in toxic, hypoxic and reperfusion injury. Mol. Cell. Biochem. 174: 159-165

8. Lemasters JJ, Nieminen AL, Qian T, Trost LC, Elmore SP, Nishimura Y, Crowe RA, Cascio WE, Bradham CA, Brenner DA and Herman B (1998) The mitochondrial permeability transition in cell death: a common mechanism in necrosis, apoptosis and autophagy. Biochim. Biophys. Acta 1366: 177-196

9. Dubinsky JM and Levi Y (1998) Calcium-induced activation of the mitochondrial permeability transition in hippocampal neurons. J. Neurosci. Res. 53: 728-741

10. Friberg H, Ferrand-Drake M, Bengtsson F, Halestrap AP and Wieloch T (1998) Cyclosporin A, but not FK 506, protects mitochondrial and neurons against hypoglycemic damage and implicates the mitochondrial permeability transition in cell death. J. Neurosci. 18: 151-159

11. Reed JC, Jurgensmeier JM and Matsuyama S (1998) Bcl-2 family proteins and mitochondria. Biochim. Biophys. Acta 1366: 127-137

12. Kluck RM, Bossy-Wetzel E, Green DR and Newmeyer DD (1997) The release of cytochrome c from mitochondria: a primary site for $\mathrm{Bcl}-2$ regulation of apoptosis. Science 275: $1132-1136$

13. Yang J, Liu X, Bhalla K, Kim CN, Ibrado AM, Cai J, Peng TI, Jones DP and Wang X (1997) Prevention of apoptosis by Bcl-2: release of cytochrome c from mitochondria blocked. Science 275: 1129-1132

14. Susin SA, Zamzami N, Castedo M, Hirsch T, Marchetti P, Macho A, Daugas E, Geuskens M and Kroemer G (1996) Bcl-2 inhibits the mitochondrial release of an apoptogenic protease. J. Exp. Med. 184, 1331-1341

15. Shimizu S, Eguchi Y, Kamiike W, Funahashi Y, Mignon A, Lacronique V Matsuda $\mathrm{H}$ and Tsujimoto $\mathrm{Y}$ (1998) Bcl-2 prevents apoptosis mitochondrial dysfunction by regulating proton flux. Proc. Natl. Acad. Sci. USA 95: 1455-1459

16. Marzo I, Brenner C, Zamzami N, Susin SA, Beutner G, Brdiczka D, Remy R, Zie ZH, Reed JC and Kroemer G (1998) The permeability transition pore complex: a target for apoptosis regulation by caspases and bcl-2-related proteins. J. Exp. Med. 187: 1261-1271

17. Murphy AN, Bredesen DE, Cortopassi G, Wang E and Fiskum G (1996) Bcl-2 potentiates the maximal calcium uptake capacity of neural cell mitochondria. Proc. Natl. Acad. Sci. USA, 93: 9893-9898

18. Ellerby LM, Ellerby HM, Park SM, Holleran AL, Murphy AN, Fiskum G, Kane DJ, Testa MP, Kayalar C and Bredesen DE (1996) Shift of the cellular oxidationreduction potential in neural cells expressing Bcl-2. J. Neurochem. 67: 12591267

19. Castilho RF, Kowaltowski AJ, Meinicke AR, Bechara EJ and Vercesi AE (1995) Permeabilization of the inner mitochondrial membrane by $\mathrm{Ca}^{2+}$ ions is stimulated by t-butyl hydroperoxide and mediated by reactive oxygen species generated by mitochondria. Free Radic. Biol. Med. 18: 479-486

20. Kowaltowski AJ, Castilho RF, Grijalba MT, Bechara EJH and Vercesi AE (1996) Effect of inorganic phosphate concentration on the nature of inner mitochondrial membrane alterations mediated by $\mathrm{Ca}^{2+}$ ions. A proposed model for phosphatestimulated lipid peroxidation. J. Biol. Chem. 271: 2929-2934

21. Kowaltowski AJ, Netto LES and Vercesi AE (1998) The thiol-specific antioxidant enzyme prevents mitochondrial permeability transition. Evidence for the participation of reactive oxygen species in this mechanism. J. Biol. Chem. 273: $12766-12769$

22. Fiskum G, Craig SW, Decker GL and Lehninger AL (1980) The cytoskeleton of digitonin-treated rat hepatocytes. Proc. Natl. Acad. Sci. USA 77: 3430-3434

23. Lenartowicz E, Bernardi $P$ and Azzone GF (1991) Phenylarsine oxide induces the cyclosporin A-sensitive membrane permeability transition in rat liver mitochondria. J. Bioenerg. Biomembr. 23: 679-688 
24. Petit PX, Goubern M, Diolez P, Susin SA, Zamzami N and Kroemer G (1998) Disruption of the outer mitochondrial membrane as a result of large amplitude swelling: the impact of irreversible permeability transition. FEBS Lett. 426:111116

25. Green DR and Reed JC (1998) Mitochondria and apoptosis. Science 281 1309-1312

26. Lehninger AL, Vercesi AE and BababunmiEA(1978) Regulation of Ca2+release from mitochondria by the oxidation-reduction state of pyridine nucleotides. Proc. Natl. Acad. Sci. USA 75: 1690-1694

27. Murphy AN, Mootha V, Bredesen DE and Fiskum G (1996) Effects of bcl-2 on mitochondrial $\mathrm{Ca}^{2+}$ uptake and proteolytic activity. Soc. Neurosc. Abstr. 22: 464.8

28. Adams JM and Cory S (1998) The Bcl-2 protein family: arbiters of cell survival. Science 281: $1322-1326$

29. Rosse T, OlivierR, Monney L, Rager M, Conus S, Fellay I, Jansen B and Borner C (1998) Bcl-2 prolongs cell survival after Bax-induced release of cytochrome c. Nature 391: 496-499

30. LiF, Srinivasan A, Wang Y, Armstrong RC, TomaselliKJ and Fritz LC (1997)Cellspecific induction of apoptosis by microinjection of cytochrome c. Bcl-xL has activity independent of cytochrome c release. J. Biol. Chem. 272: 30299-30305

31. Jurgensmeier JM, Xie Z, Deveraux Q, Ellerby L, Bredesen D and Reed JC (1998) Bax directly induces release of cytochrome $\mathrm{c}$ from isolated mitochondria. Proc. Natl. Acad. Sci. USA 95: 4997-5002

32. Andreyev A and Fiskum G (1999) Calcium induced release of mitochondria cytochrome c by different mechanisms selective for brain versus liver. Cell Death Differ. 6: 825-832

33. Kowaltowski AJ, Vercesi AE and Castilho RF (1997) Mitochondrial membrane protein thiol reactivity with $\mathrm{N}$-ethylmaleimide or mersalyl is modified by $\mathrm{Ca}^{2+}$. correlation with mitochondrial permeability transition. Biochim. Biophys. Acta 1318: $395-402$

34. Zamzami N, Marzo I, Susin SA, Brenner C, Larochette N, Marchetti P, Reed J, Kofler R and Kroemer G (1998) The thiol crosslinking agent diamide overcomes the apoptosis-inhibitory effect of $\mathrm{Bcl}-2$ by enforcing mitochondrial permeability transition. Oncogene 16: 1055-1063
35. Cai J and Jones DP (1998) Superoxide in apoptosis. Mitochondrial generation triggered by cytochrome c loss. J. Biol. Chem. 273: 11401-11404

36. Nieminen AL, Byrne AM, Herman B and Lemasters JJ (1997) Mitochondrial permeability transition in hepatocytes induced by $\mathrm{t}-\mathrm{BuOOH}: \mathrm{NAD}(\mathrm{P}) \mathrm{H}$ and reactive oxygen species. Am. J. Physiol. 272: C1286-C1294

37. Espositi MD, Hatzinisiriou I, McLennan H and Ralph S (1999) Bcl-2 and mitochondrial oxygen radicals. New approaches with reactive oxygen-sensitive probes. J. Biol. Chem.274: 29831-29837

38. Wright SC, Wang H, Wei QS, Kinder DH and Larrick JW (1998) Bcl-2-mediated resistance to apoptosis is associated with glutathione-induced inhibition of AP24 activation of nuclear DNA fragmentation. Cancer Res. 58: 5570-5576

39. Murphy AN, Myers KM and Fiskum G (1996) Bcl-2 and N-acetylcysteine inhibition of mitochondrial respiratory impairment following exposure of neural cells to chemical hypoxia/aglycemia. In Pharmacology of cerebral ischemia 1996, J. Krieglstein, ed (Stuttgart Medpharm Scientific Publishers) pp. 163-172

40. Macho A, Blazquez MV, Navas P and Munoz E (1998) Induction of apoptosis by vanilloid compounds does not require de novo gene transcription and activator protein 1 activity. Cell Growth Differ 9: 277-286

41. Ratan RR, Murphy TH and Baraban JM (1994) Macromolecular synthesis inhibitors prevent oxidative stress-induced apoptosis in embryonic cortical neurons by shunting cysteine from protein synthesis to glutathione. J. Neuroscience 14: 4385-4392

42. Ferrari G, Yan CYI and Green LA (1995) N-acetylcysteine (D- and Lstereoisomers) prevents apoptotic death of neuronal cells. J. Neuroscience 15: $2857-2866$

43. Kane DJ, Sarafian TA, Anton R, Hahn H, Gralla EB, Valentine JS, Ord T and Bredesen DE (1993) Bcl-2 inhibition of neural death: decreased generation of reactive oxygen species. Science 262: $1274-1277$

44 Åkerman KE and Wikstrom MK (1976) Safranine as a probe of the mitochondrial membrane potential. FEBS Lett. 68: 191-197

45. Andreyev AY, Fahy B and Fiskum G (1998) Cytochrome c release from brain mitochondria is independent of the mitochondrial permeability transition. FEBS Lett. 439 : $373-376$ 